\title{
Yield Curve Inversions and Cyclical Peaks
}

\author{
Richard G. Anderson
}

A 11 National Bureau of Economic Research (NBER) business cycle peaks since 1960 have been preceded by a flattening or inversion of the Treasury yield curve, leading some observers to express concern that the recent flattening of the yield curve might presage a near-term business cycle peak. However, the historical record, shown in the table, suggests that the relationship between yield curve inversions (negative slope) and subsequent economic downturns is tenuous.

In the table, the yield curve's slope is measured by the spread between Treasury constant-maturity yields at 10-year and 3-month maturities, a measure that past studies have labeled as the most reliable for predicting changes in economic activity. In the left panel, each row corresponds to a yield curve inversion, the slope having been positive during the previous month; in the right panel, each row corresponds to an NBER business cycle peak. Yield curve inversions tend to predict approximately twice as many recessions as actually occur. The durations and maximum yield spreads also vary sharply. Half of the inversions lasted 3 months or less; only three lasted 1 year or more. Half of the inversions also had maximum spreads of less than 28 basis points, with only three greater than 150 basis points. Finally, the number of elapsed months from the onset of inversion to the cycle peak also is varied.
Six episodes lasted 9 months or less; six lasted 1 year or more. Clearly, although a business cycle peak eventually followed each inversion, the timing has been imprecise.

In the right-hand panel, the first three NBER cycle peaks were not preceded by inversions (these may be unreliable because the long-term Treasury bond market was thin); only six peaks remain. The next two peaks, 1969 and 1973, are the "classic" cases in which the inversion began approximately 6 months prior to the peak and continued until after the peak. The next cycle peaks, in 1980 and 1981, occurred during the Federal Reserve's aggressive disinflationary policy and perhaps are difficult to generalize. Finally, although an inversion occurred prior to the past two peaks, in 1990 and 2001, the yield curve regained its positive slope prior to the cycle peak as the Federal Open Market Committee aggressively lowered short-term rates.

In short, the variability of inversion episodes suggests caution when interpreting changes in the yield curve as leading indicators of business cycle peaks.

A longer version of this essay is available on the author's web page at research.stlouisfed.org.

\begin{tabular}{|c|c|c|c|c|c|c|c|c|c|}
\hline \multicolumn{5}{|c|}{ Yield Curve Inversions and Cycle Peaks } & \multicolumn{5}{|c|}{ NBER Business Cycle Peaks* } \\
\hline $\begin{array}{l}\text { Beginning } \\
\text { month }\end{array}$ & $\begin{array}{l}\text { Duration } \\
\text { (months) }\end{array}$ & $\begin{array}{c}\text { Max } \\
\text { spread }\end{array}$ & $\begin{array}{l}\text { Next } \\
\text { peak }\end{array}$ & $\begin{array}{c}\text { Month to } \\
\text { peak* }\end{array}$ & Peak & $\begin{array}{l}\text { Previous } \\
\text { inversion* }\end{array}$ & $\begin{array}{l}\text { Duration } \\
\text { (months) }\end{array}$ & $\begin{array}{c}\text { Max } \\
\text { spread }\end{array}$ & $\begin{array}{c}\text { Lead } \\
\text { (months)* }\end{array}$ \\
\hline Jan 1966 & 1 & -.10 & Dec 1969 & 47 & Jul 1953 & - & & & \\
\hline Sep 1966 & 6 & -.49 & Dec 1969 & 39 & Aug 1957 & - & & & \\
\hline Dec 1968 & 3 & -.28 & Dec 1969 & 12 & Apr 1960 & - & & & \\
\hline Apr 1969 & 1 & -.17 & Dec 1969 & 8 & Dec 1969 & Jun 1969 & 9 & -.51 & 6 \\
\hline Jun 1969 & 9 & -.51 & Dec 1969 & 6 & Nov 1973 & Jun 1973 & 16 & -1.6 & 5 \\
\hline Jun 1973 & 16 & -1.6 & Nov 1973 & 5 & Jan 1980 & Nov 1978 & 18 & -3.3 & 14 \\
\hline Nov 1974 & 1 & -.04 & Jan 1980 & 62 & Jul 1981 & Oct 1980 & 12 & -3.5 & 9 \\
\hline Nov 1978 & 18 & -3.3 & Jan 1980 & 14 & Jul 1990 & Nov 1989 & 2 & -.16 & 8 \\
\hline Oct 1980 & 12 & -3.5 & Jul 1981 & 9 & Mar 2001 & Jul 2000 & 7 & -.70 & 8 \\
\hline Jun 1989 & 2 & -.16 & Jul 1990 & 13 & & & & & \\
\hline Nov 1989 & 2 & -.08 & Jul 1990 & 8 & & & & & \\
\hline Jul 2000 & 7 & -.70 & Mar 2001 & 8 & & & & & \\
\hline NOTE: * Numb & $r$ of months $b$ & een initial i & rsion and cy & peak. & & & & & \\
\hline
\end{tabular}

